\title{
Studies on pollinator fauna and their relative abundance of sunflower (H elianthus annuus L.) at Pantnagar, Uttarakhand, India
}

\author{
Vimla Goswami*, M.S. K han and U sha \\ Department of Entomology, College of Agriculture, G.B. Pant University of Agriculture and Technology, Pantnagar- \\ 263145 (Uttarakhand), INDIA \\ "Corresponding author. E-mail: vimlagoswami87@yahoo.co.in
}

Received: April 14, 2013; Revised received: J une 27, 2013; Accepted: J uly 12, 2013

Abstract: Pollinators provide key services to both natural and agricultural ecosystems. Agricultural productivity depends, in part on pollinator populations from adjacent semi natural habitats. The diversity and abundance of different insect visitors on sunflower (Helianthus annuus L.) were studied at Pantnagar. A total of 12 insect visitors belonging to order Hymenoptera (9), Diptera (1), Lepidoptera (1), and Coleoptera (1) were observed visiting the blossom of sunflower. The abundance (percentage of insect $/ \mathrm{m}^{2} / 2 \mathrm{~min}$.) of Hymenopterans were maximum (86.09 $\%)$ followed by the Dipterans (22.80\%) and others (3.87\%). In Hymenopterans, the honeybees (Apis bees) were observed maximum (65.22 \%) followed by non Apis bees $(20.39 \%)$ and the scolid wasp $(1.69 \%)$.

Keywords: Abundance, Diversity, Helianthus annuus, Pollinator

\section{INTRODUCTION}

Several agriculture and horticulture crops cultivated in India derive benefit or are dependent on pollinating insects for effecting qualitative and quantitative improvement in crops yield. Among different pollinators, bees are considered as the best pollinating agents due to their suitable body size, hairiness, thoroughness, steadfastness, floral consistency and manageable populations. About one-third of the human diet comes from insect pollinated plants, and the honey bees account for 80 per cent of pollination (FAO, 1995). Sunflower is the second most important oil seed crop in the world next to soybean. It is important crop in the temperate countries like Russia, Bulgaria, Romania, Canada and the USA. India has the fourth largest area under sunflower (2.15 $\mathrm{m} \mathrm{ha}$ ) in the world .The flowers produce abundant quantity of nectar and pollen which attract large number of honey bees. In most of the crops we largely seek for honey bees and depend on them for pollination services. However, there are many other insects especially the native bees which may play significant role in pollination. Among pollinating insects, Hymenopterans species have proved as boon for efficient and effective pollination in most of the crops (De Grandi-Hoffman and Watkins, 2000). The experiments conducted at various research centers in India revealed that the crop yield and quality of produce can be increased considerably through bee's pollination (Torchio, 1994; Greenleaf and Kremen, 2006). Bees certainly are essential in seed production of sunflower because pollen must be transferred from male- fertile to male sterile plants (De Grandi-Hoffman and Chambers, 2006). Keeping above in view the present investigation was conducted to study the pollinator fauna and their relative abundance of sunflower (Helianthus annuus L.) at Pantnagar, Uttarakhand.

\section{MATERIALS AND METHODS}

The studies were conducted at Apiary site in College of Agriculture, G. B. Pant University of Agriculture and Technology Pantnagar, Uttarakhand (India) during the year 2012. The diversity of insect visitors was recorded and the individuals collected by a hand net. Sweeps were made at peak blooming period of sun flower crop every day, at fixed time intervals. The abundance of insect visitors per sq. $\mathrm{m}$. area was recorded at hourly intervals from 10:00 to $14: 00 \mathrm{~h}$, during the blooming period of the crop. The averages of the observations were calculated.

\section{RESULTS AND DISCUSSION}

Diversity of pollinators: A total of 12 insect visitors belonging to order Hymenoptera (9), Diptera (1), Lepidoptera (1), and Coleoptera (1) were found to visit the sunflower crop (Table 1).

Hymenopteran visitors belonged to six families namely Apidae (4), Xylocopidae (1), Halictidae (2), and Magachilidae (1). Lepidopteran visitors belonged to families Pieridae (1). Besides this some Dipteran visitor belonged to families Syrphidae (1) were observed on sunflower. From the family Apidae, honeybees (Apis mellifera, A. dorsata and A. cerana indica), and stingless bee (Trigona laeviceps) were the five species that were 
Table 1. Diversity of pollinator on sunflower crop at Pantnagar.

\begin{tabular}{|c|c|c|c|c|}
\hline Insect visitor & Common name & Order & & Family \\
\hline Apis mellifera & Italian honey bee & Hymenoptera & & Apidae \\
\hline A. dorsata & Rock bee & Hymenoptera & & Apidae \\
\hline A. cerana indica & Indian honeybee & Hymenoptera & & Apidae \\
\hline Trigona laeviceps & Stingless bee & Hymenoptera & & Apidae \\
\hline M egachile disjuncta & Leaf cutter bee & Hymenoptera & & Megachilidae \\
\hline Xylocopa iridipennis & Carpenter bee & Hymenoptera & & Xylocopidae \\
\hline Anthophora sp. & Digger bee & Hymenoptera & & Anthophoridae \\
\hline Halictus spp. & Sweat bee & Hymenoptera & & Halictidae \\
\hline Nomia sp. & Alkali bee & Hymenoptera & & Halictidae \\
\hline Syrphus corollae & Syrphid fly & Diptera & & Syrphidae \\
\hline Pieris brassicae & Cabbage butterfly & Lepidoptera & & Pieridae \\
\hline Coccinella septumpunctata & Ladybird beetle & Coleoptera & & Coccinellidae \\
\hline \multirow[t]{2}{*}{ Insect groups } & \multicolumn{4}{|c|}{ A bundance of insect visitor (insect visitor $\mathrm{s} / \mathrm{m}^{2} / 2 \mathrm{~min}$ ) } \\
\hline & $10: 00 \mathrm{~h}$ & $12: 00 \mathrm{~h}$ & $14: 00 \mathrm{~h}$ & Mean \\
\hline Hymenopterans & 85.30 & 88.50 & 84.48 & 86.09 \\
\hline Apis bees & 70.80 & 66.31 & 58.55 & 65.22 \\
\hline Non Apis bees & 15.74 & 21.28 & 24.17 & 20.39 \\
\hline Wasp & 0.89 & 2.43 & 1.76 & 1.69 \\
\hline Dipterans & 20.10 & 25.66 & 22.64 & 22.80 \\
\hline
\end{tabular}

Table 3. Number of species of floral visitors on sunflower crop.

\begin{tabular}{lcccc}
\hline \multirow{2}{*}{ Insect visitors } & \multicolumn{4}{c}{ Percent abundance of pollinator s (insect visitors $/ \mathrm{m}^{2} / 2 \mathrm{~min}$ ) } \\
\cline { 2 - 4 } & $10: 00 \mathrm{~h}$ & $12: 00 \mathrm{~h}$ & $14: 00 \mathrm{~h}$ & M ean \\
\hline A pis mellifera & 80.25 & 88.26 & 83.42 & 83.97 \\
A pis dorsata & 33.73 & 40.50 & 41.30 & 38.51 \\
A pis cerana & 45.13 & 53.30 & 33.11 & 43.84 \\
A pis florea & 4.00 & 4.15 & 6.60 & 4.91 \\
H alictus spp. & 9.67 & 10.06 & 13.00 & 10.91 \\
Trigona laeviceps & 31.65 & 44.61 & 45.23 & 40.49 \\
Anthophora sp. & 22.87 & 33.89 & 25.39 & 27.38 \\
N omia sp. & 10.83 & 18.94 & 16.20 & 15.33 \\
Xylocopa iridipennis & 5.17 & 18.78 & 12.35 & 12.10 \\
M egachile disjuncta & 10.43 & 14.91 & 18.72 & 14.68 \\
Syrphus spp. & 21.30 & 33.13 & 33.73 & 29.38 \\
Others & 2.60 & 2.89 & 6.13 & 3.87 \\
\hline
\end{tabular}

recorded on the sun flowers. carpanter bee (Xylocopa iridipennis) of Xylocopidae, the Alkali Bees (Nomia sp.) and $\mathrm{H}$ alictus sp. of Halictidae, Leaf cutter bee (M egachile disjuncta) of Megachilidae, the digger bee (A nthophora sp.) of Anthophoridae and Sphex sp. of Sphecidae visited the sunflower.From Diptera family Syrphidae (Syrphus corollae). Lepidopterans namely Cabbage butterfly (Pieris brassicae) of family Pieridae was observed. Jadhav et al. (2011) observed that twenty species visiting sunflower heads that belonged to orders Hymenoptera,
Lepidoptera, Diptera and Coleoptera. Species richness was high in Hymenopterafollowed by Lepidoptera and Coleoptera. Hymenoptera comprised of two families, Lepidoptera of four families, Coleoptera of three families and one family under Diptera. A. mellifera L. was the most important pollinator of sunflower in France while the other pollinator fauna included five species of B ombus, H alictus and Andrena (Delaude et al., 1978).

Relative abundance of different pollinators: The abundance (percentage of insect $/ \mathrm{m}^{2} / 2 \mathrm{~min}$.) of 
Hymenopterans were maximum $(86.09 \%)$ followed by the Dipterans $(22.80 \%)$ and others $(3.87 \%)$. In Hymenopterans, the honeybees (Apis bees) were observed maximum $(65.22 \%)$ followed by non Apis bees $(20.39 \%)$ and the scolid wasp $(1.69 \%)$. The Italian honey bee (A pis mellifera) was maximum $(83.97 \%$ ) followed by A. cerana indica (43.84\%), A. dorsata (38.51\%), A. flor ea (4.49\%), the stingless bee ( $40.49 \%)$, H alictus spp. (10.91 $\%$ ), Anthophora sp. (27.38\%), X. iridipennis (12.10\%), and Syrphus spp. (29.38\%) of the insect visitors on sunflower was recorded. Maximum abundance of $A$ mellifera was observed at $1200 \mathrm{~h}$ with mean of 88.26 and least $(80.25)$ at $1000 \mathrm{~h}$. According to Swaminathan and Bhardwaj (1982), A. dorsata formed the chief pollinator and constitute about $81.20 \%$ of the total insect visitors followed by A. florea (8.23\%), Lasioglosum sp $(3.75 \%)$, Pithitis Smaragdula (2.37\%), Xylocopa sp. (0.14\%), and Chalicodoma lerma $(0.13 \%)$ (Tables 2 and 3$)$. Ahmed et al. (1989) found that among the insects visiting sunflower, Hymenopterous species were the most important pollinators and honeybees formed 75 per cent of Hymenoptera on sunflower. Other bees which visited the crop and directly affected yield were Bombus spp., N omia melanderi, M egachile rotundata and $\mathrm{H}$ alictus sp (Moreti et al., 1996) .

\section{Conclusion}

In conclusion, this study provides insights into the importance of pollinator insects to help plant pollination, included sun flower an importance crop in the tropic. It is clear from present finding that the sunflower capitulum in bloom is highly attractive to multitude of insect species, especially those belonging to Hymenoptera and Diptera. The results indicate a diversity and abundance of pollinator insects, especially bees, plays a significant role in seed set of sunflower. Hence, conservation of bee species by encouraging increased forage crops in the vicinity of cropped areas is recommended which enriches biodiversity along the line.

\section{REFERENCES}

Ahmed, H.M.H; Siddig, M.A. and Sarrag, M.S.A. (1989). Honeybee pollination of some cultivated crops in Sudan. Proceedings of the Fourth International Conference on Apiculture in Tropical Climates, Cairo, Egypt, 6-10 November 1988. 100-108.

De Grandi-Hoffman. G and Chambers. M. (2006). Effects of honeybee (Hymenoptera: Apidae) foraging on seed set in self-fertile sunflowers Helianthus annuus L. Environ. Entomol. 35(4): 1103-1108

Degrandi-Hoffmann, G. and Watkins, J.C. (2000). The foraging activity of honeybees Apis mellifera and non Apis bees on hybrid sunflower (Helianthus annuus)and its influence on cross-pollination and seed set. J ournal A picultural Research $39,37-45$.

Delaude, A; Tasei, J. N. and Roller, M. (1978). Pollinator insects of sunflower (Helianthus annuus L.) in France, pollination of male sterile lines of hybrid seed production. Proc. IV Int. Sym. on Pollination, Maryland, 29-40.

FAO, (1995). Pollination of cultivated plants in the tropics. Agric. Serv. Bull. no. 118, 198.

Greenleaf, S. S. and Kremen, C. (2006). Wild bees enhance honeybees' pollination of hybrid sunflower. Proceeding of the National Academy of Science, USA, 103, 1389013895.

Jadhav, J. A; Sreedevi, K. and Rajendra P. (2011). Insect pollinator diversity and abundance in sunflower ecosystem. Current Biotica, 5(3): 344-350

Moreti, A. C.; Silva, R. M. B; Silva, E. C. A., Alves, M. L. T. and Otsuk, I. P. (1996). Increase of sunflower (Helianthus annuus L.) seed production by pollinating insect action. Scientia Agricola 53(2/3): 280- 284.

Swaminathan, R. and Bhardwaj, S. C. (1982). Bee pollinators of sunflower and their foraging behaviour. Indian Bee J ournal, 44(2): 32-34.

Torchio, P. F. (1994). The present status and future prospects of non-social bees as crop pollinators. Bee World, 75(2): 49-53. 